\title{
KARBANTARTÓ SZAKEMBEREK VÉLEMÉNYEINEK ELEMZÉSE
}

\section{INVESTIGATION OF MAINTENANCE EXPERTS' OPINIONS}

\author{
Ágoston Gábor ${ }^{1}$, Pokorádi László ${ }^{2}$ \\ ${ }^{I}$ Óbudai Egyetem Bánki Donát Gépész és Biztonságtechnikai Mérnöki Kar, \\ Magyarország 1081 Budapest, Népszínház u. 8. agostongabe@gmail.com \\ ${ }^{2}$ Óbudai Egyetem, Mechatronikai és Jármütechnikai Intézet, \\ Magyarország 1081, Budapest, Népszinház utca, 8. +36 3099194929, \\ pokoradi.laszlo@bgk.uni-obuda.hu
}

\begin{abstract}
One of the most important "task" of technical management's decision making is showing scale of values of given part of engineering. It plays a decisive role in the decision of maintenance management. This paper shows the results of our micro experiments conducted as part of a long-winded research and its comparison are presented.
\end{abstract}

Keywords: decision making; maintenance; pairwise comparison

\section{Összefoglalás}

A müszaki vezetők döntésének egyik mozgató rugója az adott szakterület sajátosságain alapuló értékrend képviselete. Ez meghatározó szerepet játszik például a karbantartással kapcsolatos döntéshozatalban. Tanulmányunkban egy nagyobb lélegzetü elemzés részeként elvégzett mikro kísérlet eredményeit és azok összehasonlítását mutatjuk be. A kapott eredmények a Szerzők további kutatómunkájának alapjait képezik.

Kulcsszavak: döntéshozatal; karbantartás; páros összehasonlitás;

\section{Bevezetés}

A karbantartási döntések meghozatalakor fontos szempont lehet a különböző rendszer, illetve folyamatjellemzők szakmaspecifikus súlyának ismerete [1].

Jelen dolgozatunk célkitüzése meghatározni, hogy a különböző területeken dolgozó karbantartó szakemberek véleménye szerint a vizsgált három szempont milyen sorrendü és arányú fontossággal bír.

A tanulmány az alábbi fejezetekből áll: A 2. fejezet a páros összehasonlítás módszerét mutatja be, röviden. A 3. fejezet két karbantartási terület szakembereinek szakma-specifikus véleményét tárja fel. A 4. fejezetben a kapott eredmények elemzése olvasható. Végezetül az 5. fejezetben a Szerzők összegzik munkájukat.

\section{A páros összehasonlítás mód- szere}

A páros összehasonlítás célja, megalkotni egy olyan kompromisszumos döntéseken alapuló értékrendet, amelyek az egyes szakirányok fontossági sorrendjét tükrözik, és amelyek a későbbi elemzések során fontos megállapításokat, esetleg változtatási lehetőségeket adnak a döntéshozó szakemberek és szervek számára [3]. 
Szükségszerü, hogy a vizsgált kérdéskör elemzésére vonatkozóan szempontokat ütköztessünk, hogy a szakemberek döntésükről egyértelmüsített preferenciát alkossanak meg.

Az első feladat az értékelési tényezők meghatározása. Ezeket a kérdőív elkészítésekor szakmai és gyakorlati tapasztalatok alapján vettük figyelembe.

A három értékelési tényezőt (költség, munkaigény, javítási idő) figyelembe véve elkészíthető párok száma:

$$
\left(\begin{array}{l}
n \\
2
\end{array}\right)=\frac{n(n-1)}{2}=\frac{3(3-1)}{2}=3
$$

A párokba rendezett három értékelési tényezők alapján az adott szakértők az általuk fontosnak ítélt szempontokra egyértelmü szavazatot tesznek.

Az így elvégzett páros összehasonlítás alapján készítjük el a preferenciatáblázatot, mely egy $n \times n$ méretü mátrix.

E táblázat célja végső soron az, hogy az egyes $E_{i}$ értékelési tényezőkhöz hozzárendeljük az $S_{i}$ súlyszámokat.

Több új oszlop felvezetése indokolt a preferenciatáblázatba az utolsó szempontja után, amely segíti a további számítást. A preferenciák gyakoriságát az $a$ oszlopban kell összesíteni, mely az adott sor összegzése.

A Guilford-módszer segítségével az egyes szakértők konzekvenciája is megállapítható [2]. Ennek részletes ismertetése a terjedelem miatt nem lehetséges, további irodalmakban leírásra kerül.

Ha $m$ számú döntéshozó van, akkor az alábbi általános, súlyozott preferenciaarányt számíthatjuk ki:

$$
p_{i}=\frac{a_{i}+\frac{m}{2}}{m n}
$$

ahol:

$p_{i}-i$-edik elem preferenciaaránya $a_{i}-$ az $i$-edik sorban szereplö föszempont

preferenciagyakorisága

$n$ - az értékelési tényezők száma

$m$ - szakemberek száma

A következő oszlopban a preferenciaarányokat a standard normál eloszlás úgynevezett $u$ értékeire transzformáljuk:

$$
p_{i}=\Phi\left(u_{i}\right)
$$

Annak érdekében, hogy egy 0 kezdőpontú és 100 végpontú skálán értékelhessük a kapott eredményeket, a következő transzformációt kell elvégezni:

$$
Z=100 \frac{u-\min \left(u_{i}\right)}{\max \left(u_{i}\right)-\min \left(u_{i}\right)}
$$

Az adatok kiértékeléséhez és a diagramok illusztratív ábrázolásához szükséges a súlyszám-meghatározás:

$$
S_{i}=0,1+\frac{0,1 Z_{i}}{25}
$$

A súlyszámok képletéböl látható, hogy

$$
0,1 \leq S_{i} \leq 0,5 \quad \text {. }
$$

\section{Szakemberek válaszainak érté- kelése}

A szakemberek véleményének feltérképezéséhez az alábbi kérdést tettük fel, a megadott szempontok közül csak kettőt említve: „Az alábbi két szempont közül melyiket tartja fontosabbnak a karbantartásjavitás hatékonyságának megítélése szempontjából?"

$$
\begin{array}{ll}
\boldsymbol{F}_{1} & \text { javítási költség } \\
\boldsymbol{F}_{2} & \text { javítási munkaigény } \\
\boldsymbol{F}_{3} & \text { javítási idő }
\end{array}
$$

A karbantartó szakembereket szakterületekként külön kérdeztük meg. Az alábbiakban csak két területről kapott - viszonylag kevés számú - válaszokat értékeljük ki, majd hasonlítjuk össze. 


\subsection{Légi jármúvek karbantartó} szakemberek véleménye

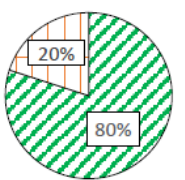

Munkaigény

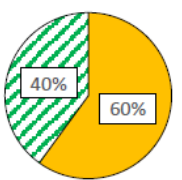

Költség

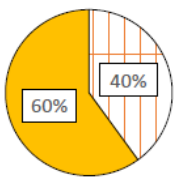

Javítási idő
1. ábra. A légijármü-karbantartó szakemberek válaszainak megoszlása

1. táblázat. $A$ válaszok értékelése

\begin{tabular}{|c|c|c|c||c|}
\hline & $\boldsymbol{F}_{\boldsymbol{1}}$ & $\boldsymbol{F}_{\boldsymbol{2}}$ & $\boldsymbol{F}_{\mathbf{3}}$ & $\boldsymbol{S}$ \\
\hline $\boldsymbol{F}_{\boldsymbol{1}}$ & 0 & 1 & 2 & 0,1 \\
\hline $\boldsymbol{F}_{\boldsymbol{2}}$ & 4 & 0 & 2 & 0,5 \\
\hline $\boldsymbol{F}_{\mathbf{3}}$ & 3 & 3 & 0 & 0,5 \\
\hline$\sum$ & 7 & 4 & 4 & \\
\hline
\end{tabular}

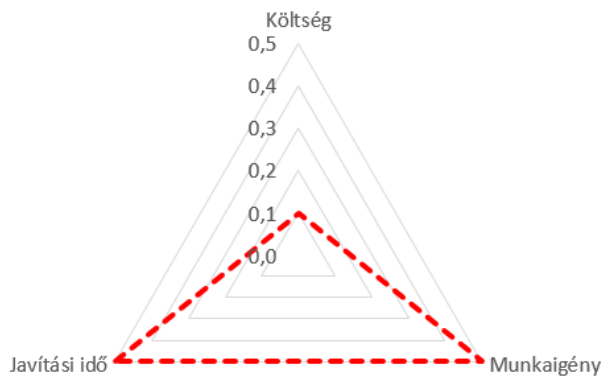

2. ábra. A légijármü-karbantartó szakemberek válaszainak értékelése

A légi jármüvek karbantartó szakembereitől érkezett válaszok alapján általánosságban elmondható, hogy számukra a munkaigény mellett hasonlóan releváns a karbantartás minél rövidebb idő alatt történő elvégzése. Ez a két szempont a repülés területén dolgozó szakembereknek és döntéshozóiknak kiemelkedően fontos, míg a rájuk szánt költségeket kevésbé relevánsnak jelölték meg, ezt mutatja, hogy ez utóbbi súlyozott értéke ötödét teszi ki az előző két szempontnak. Ennek oka „polgári esetben” például a sürgős légi mentés elmaradás kockázata. Katonai repülés esetében pedig a hadrafoghatóság kerülhet veszélybe.

\subsection{Elektromos elosztóhálózat kar- bantartó szakemberek véleménye}
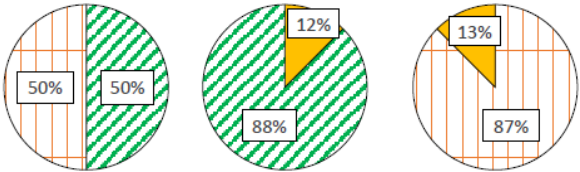

C. Munkaigény

Költség

Javítási idő

3. ábra. Elektromos elosztóhálózat szakemberek válaszainak megoszlása

2. táblázat. $A$ válaszok értékelése

\begin{tabular}{|c|c|c|c||c|}
\hline & $\boldsymbol{F}_{\boldsymbol{1}}$ & $\boldsymbol{F}_{\mathbf{2}}$ & $\boldsymbol{F}_{\mathbf{3}}$ & $\boldsymbol{S}$ \\
\hline $\boldsymbol{F}_{\boldsymbol{1}}$ & 0 & 4 & 7 & 0,5 \\
\hline $\boldsymbol{F}_{\mathbf{2}}$ & 4 & 0 & 7 & 0,5 \\
\hline $\boldsymbol{F}_{\mathbf{3}}$ & 1 & 1 & 0 & 0,1 \\
\hline$\sum$ & 5 & 5 & 14 & \\
\hline
\end{tabular}

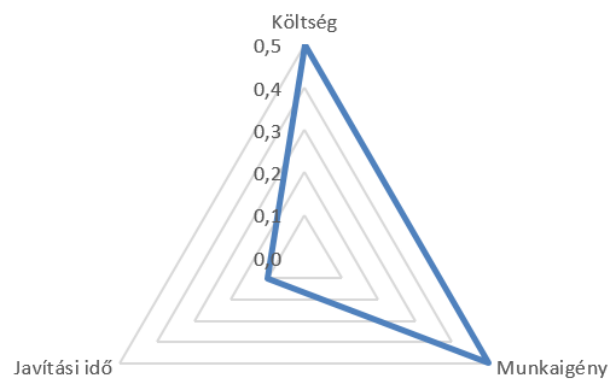

4. ábra. Elektromos elosztóhálózat karbantartó szakemberek válaszainak értékelése

A légi jármüvek karbantartóinál több válasz érkezett az elektromos elosztóhálózatok karbantartási területének szakembereitől.

Válaszaik tükrében kijelenthető, hogy ők a legkevésbé lényegesnek a javítási időt tartották, mely a preferenciatáblázat súlyozott értékeinek oszlopából is jól látható. Az elektromos hálózatok karbantartása esetében a karbantartó szakemberek ugyanolyan fontosnak tartják a javítás, karbantartás munkaigényét és annak költségeit. 


\section{Következtetések}

A 2. és 4. ábrák összevetéséből egyértelmüen jelentős különbség látszik a két karbantartási terület szakemberei gondolkozásában. Mindkét terület karbantartói számára fontos kérdés a javítás - munkaórában meghatározott - munkaigénye. Míg a repülőmüszakiak legfontosabb feladatuknak az időben mielőbbi hibajavítást tartják, addig a villamos energia elosztóhálózatok karbantartóit már sokkal jobban érdekli a felmerülő költség kérdése.

Miért lehet ez fontos számunkra?

Például egy új javítási technológia esetén nem mindegy a két terület karbantartói számára, hogy a javítási munkaigényen túl a költség vagy a javítás naptári ideje lesz kevesebb. Adott esetben, a több lehetséges javítási technológia, vagy javítási munkaszervezés közül a szakterületek igénye alapján más és más lesz az ideális választás.

Más megfogalmazásban, elemzésünkkel kimutattuk, hogy az itt bemutatott két szakterület számára optimális javítási technológia nem egyezik meg.

\section{5. Összefoglalás}

Vizsgálatunk során a karbantartó szakemberek véleményének összehasonlítását és elemzését végeztük el. Jelen publikációnkban csak két részterület eredményeit mutattuk be, terjedelmi okok miatt.

A teljes elemzésünk eredményeit további kutatásaink során tervezzük felhasználni, amikor a szakterületek - már ismertté vált fontossági arányaik alapján, úgynevezett súlyozott érzékenységvizsgálattal rangsoroljuk a lehetséges javítási technológiákat.

\section{Szakirodalmi hivatkozások}

[1] Ágoston, G.: Karbantartó szakemberek véleményének elemzése páros összehasonlitás módszerével TDK dolgozat ÓE. BGK, Budapest, 2016. (Konzulens: Pokorádi László)

[2] Kavas, L.: A súlyszámok problematikája komplex rendszerek értékelése során, Repüléstudományi Közlemények 2007/2

[3] Kindler, J.; Papp, O.: Komplex rendszerek vizsgálata, összemérési módszerek, Müszaki könyvkiadó, Budapest, 1977.

[4] Pokorádi L.: Availability Assessment Based on Stochastic Maintenance Process Modeling, Debreceni Müszaki Közlemények 2013/1, pp. 37-46.

\section{Köszönetnyilvánítás}

Tanulmányunk az Óbudai Egyetem Bánki Donát Gépész és Biztonságtechnikai Mérnöki Kar Műszaki Biztonságtudományi Szakmühely $-\boldsymbol{\mu} \boldsymbol{\beta} \boldsymbol{\sigma}-$ keretében készült el.

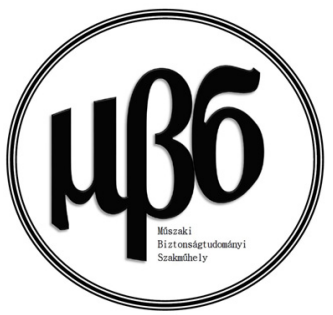

